\title{
BOOKS
}

ON HISTORY (ANCIENT, MEDIEVAL

AND MODERN), PATRISTICS,

SCHOLASTICISM, \&c : ENGLISH \&

FOREIGN, NEW \& SECONDHAND.

Large or small collections bought

W. HEFFER \& SONS LTD.

3-4, PETTY CURY, CAMBRIDGE

\section{Habits change}

But habits also grow. The habit of reading The Times usually lasts a lifetime. It begins at school or university and is proof against mere fluctuations of newspaper fashion. Those of us who look for full and accurate news find it in The Times. We come to depend on The Times for a reliable account of the day's events and the world's opinion, and we soon discover there is no substitute for

\section{THE TIMES}

